
Digitized by the Internet Archive in 2011 with funding from University of Toronto 






\section{CONTRIBUTIONS OF THE}

\section{ROYAL ONTARIO MUSEUM OF PALAEONTOLOGY}

NO. 12: A NEW LOCALITY FOR FOSSIL FISHES AND EURYPTERIDS IN THE MIDDLE DEVONIAN OF GASPE, QUEBEC.

BY LORIS S. RUSSELL 



\title{
A NEW LOCALITY FOR FOSSIL FISHES AND EURYPTERIDS IN THE MIDDLE DEVONIAN OF GASPE, QUEBEC
}

\author{
BY LORIS S. RUSSELL
}

Introduction. Localities for Devonian vertebrates of the Old Red Sandstone facies are not common in North America. The majority occur in the Appalachian region of eastern Canada. The most famous locality is that at Maguasha on Escuminac (Scaumenac) bay, in the southwestern corner of the Gaspé peninsula (Alcock, 1935: Russell, 1939). The geological position here is Upper Devonian. A Middle Devonian occurrence, known for many years, is at the local base of the Gaspé sandstone just west of Campbellton, New Brunswick (Alcock, 1935, p. 80). A single specimen of a Cephalaspis, the type of $C$.dawsoni (Lankester, 1870), was obtained by Sir William Dawson at an unspecified locality on the north side of Gaspé bay. Outside of the Gaspé region, fragments of fossil fishes were collected by H. M. Ami from the Lower Devonian Knoydart formation on McAras brook, north of Antigonish, Nova Scotia (Williams, 1914, p. 75). In recent years the discovery of a rich Lower Devonian fauna on Beartooth Butte, Wyoming (Bryant, 1932, 1933), has extended the range of the facies into the Rocky Mountain region.

The present announcement concerns the discovery of a new locality for fish remains, with eurypterids in association, in the Gaspé region. The site is on the north side of Gaspé bay, but it is not considered to be the same as that from which Sir William Dawson obtained his specimens.

History of the discovery. So little information is usually available on the events leading to the discovery of the earlier known localities that it is proposed to give a full account in the present instance. During the field season of 1946 the Department of Mines, Province of Quebec, engaged me to make a detailed stratigraphical study of the Lower Devonian Gaspé limestone series as developed on the Forillon peninsula, at the northeast corner of Gaspé bay. These rocks are almost exclusively of marine deposition, and it was not anticipated that any interesting vertebrate remains would be discovered during this work. However, our camp was established in tourist cabins just east of D'Aiguillon post office, which is located on Highway 6 about 19.5 miles by road from the town of Gaspé, and about 8 miles by road from Cap des Rosiers village. Just to the west of D'Aiguillon is the promontory of Gros Cap aux Os, and on either side of this the sea cliffs expose good sections of the Gaspé sandstone. Although these rocks were not within the field of my investigation, the possibility of obtaining vertebrate remains from them led me to examine them whenever the main programme of work would permit. On 11th July, while prospecting these clifts for fossil fishes I discovered a bone bed almost directly in front of our camp. Preliminary work revealed the presence of Cephalaspis. like remains, and I secured the permission of the Quebec Department of Mines for Mr. G. E. Lindblad, of the Royal Ontario Museum of Palaeontology, to come to Gaspé and supervise the excavation of a representative collection. In the meantime the Quebec authorities sent Mr. René Bureau, of the Department of Geology, Laval University, to assist Mr. Lindblad, and the head of that department, L'abbe J. W. Laverdière, also joined us. When weather conditions prevented continuing the main field work, help was also given by my assistant, Mr. André Larochelle, and myself. The first eurypterid from this locality was found by Mr. Bureau.

The co-operation and assistance given by the Quebec Department of Mines is greatly appreciated. It is planned to conduct further excavations at D'Aiguillon to secure as large a collection of good material as possible: A representative suite will be deposited in the collections of the Quebec Department of Mines, but all types will remain in the Royal Ontario Museum of Palaeontology. Thanks are also due to Mr. H. Cassivi, of D'Aiguillon, for permitting the excavation on his property.

Geographical data. As noted above, the fossil locality is situated on the sea cliff a short distance to the east of D'Aiguillon post office, which is in Cap des Rosiers township, Gaspé county, Quebec. Figure 1 is an outline map of the beach at D'Aiguillon, showing the position relative to the post oftice, the old wharf, and Gros Cap aux Os. The site is directly south of the Cap aux Os Hotel, operated by Mr. H. Cassivi, who is also the owner of the property. It can be reached by following the right side of the small stream, which crosses Highway 6 at this point, to the edge of the sea cliff, or by walking along the beach east from the wharf until the small stream is seen cascading down the bedding planes of the rock. The bone bed is situated almost immediately to the west of this stream. 
Geological dala. The D'Aiguillon bone bed lies well up in the Gaspe sandstone series of Logan, and is part of what Kindle $(1938,1) .29)$ called the Peninsula facies. More recently McGerrigle (1946) has designated this portion of the series as the Battery Point formation. The base of the Gaspé sandstone outcrops in a small stream bed on the hillside north of D'Aiguillon. The elevation here is about 600 feet above sea level. Average strike for the area between here and the beach is about north $300^{\circ}$ east. Horizontal distance across strike from bone bed to base of formation is about 4,500 feet. Taking as the average dip an angle of $38^{\circ}$, we may calculate that the D'Aiguillon bone bed lies about 2,300 feet above the base of the Gaspé sandstone series.

At D'Aiguillon the beds are dipping about $40^{\circ}$ to the southwest, with a strike of about north $314^{\circ}$ east. As a result the cliff face almost coincides with the bedding planes, but the individual strata trend in from the face westward at a slight angle. This means that the removal of overburden from a particular bed becomes slowly but progressively more laborious as it is followed from its outermost limit.

The following columnar section measured across the cliff adjacent to and including the bone bed serves to inclicate the nature of the fossiliferous strata and of those immedi. ately above and below. Most of the lithological types described can be duplicated many times in the Battery Point formation.

Section of Battery Point beds (Gaspe sandstone series) at the fossil LOCALITY NEAR THE EAST END OF D'AIGUILLON BEACH

Sandstone, coarse grained, finely conglomeratic in places, with grains of pink calcite; thin bedded to massive, with much cross bedding; colour light grey-buff

Shale, non-calcareous, friable; colour maroon, with thin beds of light green.

Shale, non-calcareous, finely friable; colour grey, greenish grey, and reddish brown

Shale, non-calcareous, slightly arenaceous, platy, relatively hard, ledgeforming; colour greenish grey

Shale, non-calcareous, finely friable, platy in places; colour grey-brown and grey-green :

Shale, fissile, finely arenaceous, ledge-forming; colour greenish grey to grey .

Shale, carbonaceous, finely fissile, colour dark grey; maximum .

Shale, finely friable, with irregular beds of harder, arenaceous shale; colour ranges from grey-green and grey to maroon

Shale, arenaceous, ledge-forming, platy; colour maroon, grey, and greenish grey

Shale, arenaceous, friable above, becoming platy and ledge-forming below; colour grey-green

Shale, non-calcareous, finely friable; colour greenish grey above, shading to maroon-grey below

Shale, non-calcareous, rela tively hard, breaking into angular fragments, with conchoidal partings; harder, ledge-forming layer $0.7 \mathrm{ft}$. from top; colour dark bluish grey, with rusty stains; fossils include small pelecypods, eurypterids, and rare Cephalaspis; this member designated for convenience the eurypterid shale .

Mudstone, hard, ledge-forming, with conchoidal jointing which results in a series of parallel half-cylindrical masses, trending horizontally in to cliff along the bed; colour greenish grey with rusty stains; fossils include abundant but vague impressions of aquatic plants, numerous fragments of Cephalaspis and probably placoderms, and occasional fragments of eurypterids; for convenience this member is designated the bone bed .

Shale, friable, moderately hard, filling angular spaces between curved joint planes of bone bed; colour greenish grey to grey . . . . .... .

Mudstone, somewhat arenaceous, hard, ledge-forming; colour grey-brown or maroon-grey

Sandstone, hard, ledge-forming, fine-grained, argillaceous, partly shaly, cross bedded, friable to massive; colour greenish grey, with rusty stains .

Shale, friable; colour greenish grey . . . . . . . . . . . .

Sandstone, fine, hard, ledge-forming, massive, cross bedded, platy in places; colour light grey, with faint reddish tinge in places . . . . . .

Shale, somewhat arenaceous, coarsely friable; colour grey, with greenish and reddish stains

$13 \mathrm{ft}$

$6.5 \mathrm{ft}$.

$13 \mathrm{ft}$.

$\pm 0.3 \mathrm{ft}$.

$1.5 \mathrm{ft}$.

$1.8 \mathrm{ft}$

$0.1 \mathrm{ft}$.

$11.5 \mathrm{ft}$.

$1.5 \mathrm{ft}$.

$3.7 \mathrm{ft}$.

$7 \mathrm{ft}$.

$3 \mathrm{ft}$.

$0.1-0.3 \mathrm{ft}$.

$0.8 \mathrm{ft}$.

$4.7 \mathrm{ft}$.

$1.6 \mathrm{ft}$.

$3.5 \mathrm{ft}$.

Shale. etc. 
The photograph reproduced in figure 2 shows the fossil beds as seen from the beach, and that of figure 3 shows the details of the eurypterid shale and the bone bed.

Notes on the fauna. It is hoped to complete two preliminary papers on the fossils of the D'Aiguillon locality, one on the invertebrates, and a second on the vertebrates. These descriptions will necessarily be preliminary because the additional collecting planned for 1947 should provide further information on the known forms, and possibly some specimens of organisms not presently represented. The following notes are intended only to give a general picture of the assemblage, and the mode of preservation.

The plant remains consist of somewhat vague carbonaceous films of undulating form. The better preserved examples show a stellate arrangement of the thalli, suggesting material figured by Dawson $(1871$, pl. 6, fig. 70) as Annularia laxa. Whether or not Dawson's material was the same as that obtained at D'Aiguillon, the present specimens are much more suggestive of a simple, aquatic, floating type of plant. These plant remains are most abundant in the middle and lower portions of the bone-bed layer, and do not occur in the overlying shale.

The most abundant invertebrate is a small pelecypod, with thin shell and elongate. inequilateral valves. Variations in the shape are probably the result of distortion. More work is required to identify this form, but it suggests a small-shelled species of Modiomorpha. These little valves, averaging about $12 \mathrm{~mm}$. in length, are most abundant in the eurypterid shale just at its base, but also occur in the top of the bone bed. A small gastropod, of generalized, viviparid-like form, was obtained from the bone bed.

The most striking invertebrate is the large eurypterid, which is best preserved in the lower part of the eurypterid shale, but fragments of which do occur in the upper part of the bone bed. Specimens showing the entire dorsal surface of the cephalothorax and most of the abdomen have been found. The appendages are poorly represented, and examples of the telson have not been observed. The very characteristic ornamentation is a scale-like pattern, especially well shown on the tergites. These "scales" are broadly semicircular near the anterior margin of the segments, but become almost linear posteriorly. This ornamentation, together with the marginal position of the eyes, and the general shape of the body, indicate that a species of Pterygotus is represented. The size is about that of P. buffaloensis Pohlman, and the complete body probably measured about $700 \mathrm{~mm}$. in length. Whiteaves (1881) recorded some fragments of a Pterygotus from the Gaspé sandstone at Campbellton, N.B., and Clarke and Ruedemann (1912, p. 356) made these the types of $P$.atlanticus, sp. nov. Assuming that this material is adequate for the definition of the species, it is impossible at present to decide whether or not the D'Aiguillon specimens pertain to P.atlanticus. The corresponding parts of the animal are not represented in the two lots of material. The general similarity of the provenience, however, suggests that the D'Aiguillon specimens should be referred to Pterygotus ?atlanticus until the question can be settled from a more comprehensive collection.

The determinable fish remains consist almost entirely of portions of the head shield of Cephalaspis. These are mostly confined to the upper portion of the bone bed. In places the material consists of abundant small fragments. Elsewhere the entire rim of the shield may be preserved. In such cases the thinner, central part of the head has been largely broken away, leaving the rim, with cornua, like an open horse-shoe. Fragments of the medial surface, including the orbital region, also occur. Portions showing the lateral or dorsal fields were not observed. In the lower part of the eurypterid shale an occasional specimen may be found. Here the preservation is different; the entire dorsal surface including rim may be present in undistorted condition. However, the bone tends to cleave through the middle, and is much more difficult to separate from the matrix than in the case of the bone bed material.

From various specimens representing both occurrences a composite picture of the head shield may be developed. The size is relatively large, length from anterior margin to cornua being $132 \mathrm{~mm}$. in one example. There is no trace of a rostrum, the anterior margin being well rounded. In outline the head shield is moderately narrow, having about the proportions of the head in C. lyelli Ag. (Stensio, 1932, p. 118). The orbits are situated close together, and well in advance of mid-length. From the orbital area the surface slopes almost straight to the margin. The posteromedial margin is not preserved in any of the specimens.

The DAiguillon specimens of Cephalaspis are not referable to any of the various species previously described from the Gaspé and Bay of Chaleur localities (Robertson, 1936). C. dawsoni, also from the Gaspé sandstone on the north side of Gaspé bay, is a small form, with broad. crescentic head shield. The type and only specimen of this 
species is preserved in flattened form on laminated shale. From the Gaspé sandstone at Camplellton, N.B., several species have been described (Robertson, 1936), but with one exception these are distinctly rostrate. C. jexi, the non-rostrate species from here (not Escuminac bay, as stated by Robertson), has stout, denticulate cornua. The two species known from the Upper Devonian of Escuminac Bay (Maguasha) have broad head shields with stout cornua. The only other North American species, $C$. wyomingensis Bryant $(1933$, p. 312$)$, has widely separated orbits. From these comparisons it is concluded that the D'Aiguillon specimens must form the basis of a new species. Formal definition of this species will be reserved for a later occasion.

The only other vertebrate remains observed in the D'Aiguillon collection are thin plates of bone bearing an ornamentation of fine tubercles arranged in concentric rows ${ }^{*}$ These comparatively rare specimens represent a placoderm, possibly Phlyclaenaspis, the remains of which are abundant among the Campbellton material.

\section{BIBLIOGRAPHY}

Alcock, F. J., 1935, "Geology of Chaleur Bay Region," Canada, Dept. of Mines, Geol. Surv., Mem. 183, 146 pp., 15 figs., 16 pls., 1 map.

Bryant, W. L., 1932, "Lower Devonian fishes of Beartooth Butte, Wyoming," Proc. Amer. Philos. Soc., vol. 71 , pp. $225-251$, figs. $1-6$, pls. 1-10.

Bryant, W. L., 1933, "The fish fauna of Beartooth Butte, Wyoming," Proc. Amer. Philos. Soc., vol. 72, pp. 285-314, figs. 1-8, pls. 1-21.

Clarke, J. M., and Ruedemann, R., 1912, "The Eurypteridae of New York," N.Y. Statc Mus., Mem. 14, 628 pp., 121 figs., 88 pls.

Dawson, J.'W., 1871, "The fossil plants of the Devonian and Upper Silurian formations of Canada," Geol. Surv. Canada, 92 pp., 4 figs., 20 pls.

KindLE, E. M., 1938, "The correlation of certain Devonian faunas of eastern and western Gaspé," Bull. Amer. Paleont., vol. 24, no. 82, 52 pp., 2 pls.

LANkester, E. R., 1870, "On a new Cephalaspis discovered in America, etc.," Geol. Mag., vol. 7, pp. 397 398, figs. $1-3$.

McGerrigle, H. W., 1946, "A revision of the Gaspé Devonian," Trans. Roy. Soc. Canada, ser. 3, vol. 40, sec. 4 (in press).

Robertson, G. M., 1936, "New cephalaspids from Canada," Amer. Jour. Sci., vol. 31, pp. 288-295, figs. 1-4.

RusSELL, L.S., 1939, "Notes on the occurrence of fossil fishes in the Upper Devonian of Maguasha, Quebec," Contrib. Roy. Ont. Mus. Palaeont., no. 2, 10 pp., 1 pl.

Stensio, E. A., 1932, "The cephalaspids of Great Britain," Brit. Mus. (Nat. Hist.), 220 pp., 70 figs., 66 pls.

Whiteaves, J.F., 1883, "On some fossil fishes, Crustacea \& Mollusca from the Devonian rocks at Camphellton, N.B., with descriptions of five new species," Canad. Naturalist, n.s., vol. 10, pp, 93-101, 1 fig.

Williams, M. Y., 1914, "Arisaig-Antigonish district, Nova Scotia," Canada, Dept. Mines, Geol. Surv. Mem. 60, 173 pp., 2 maps. 


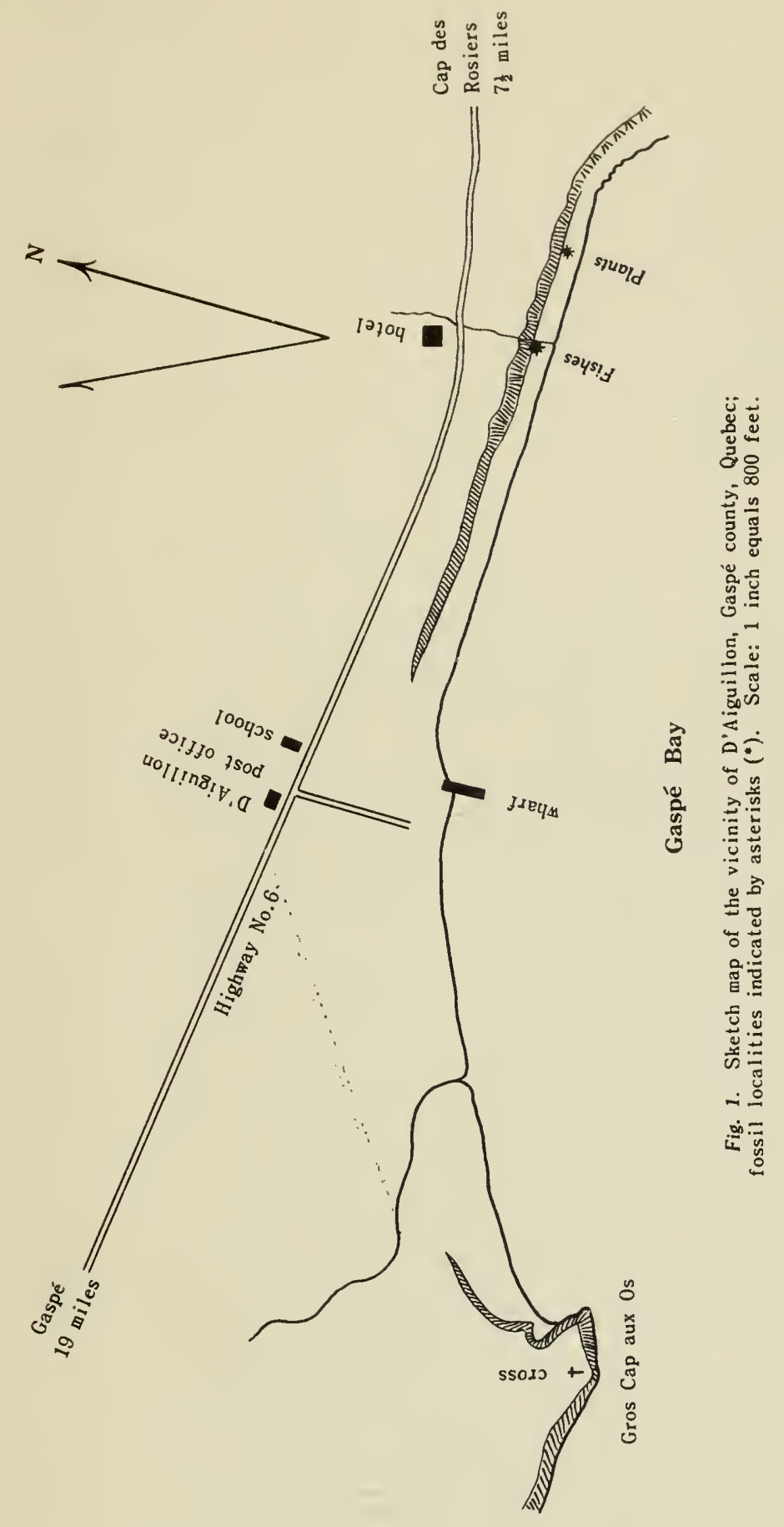




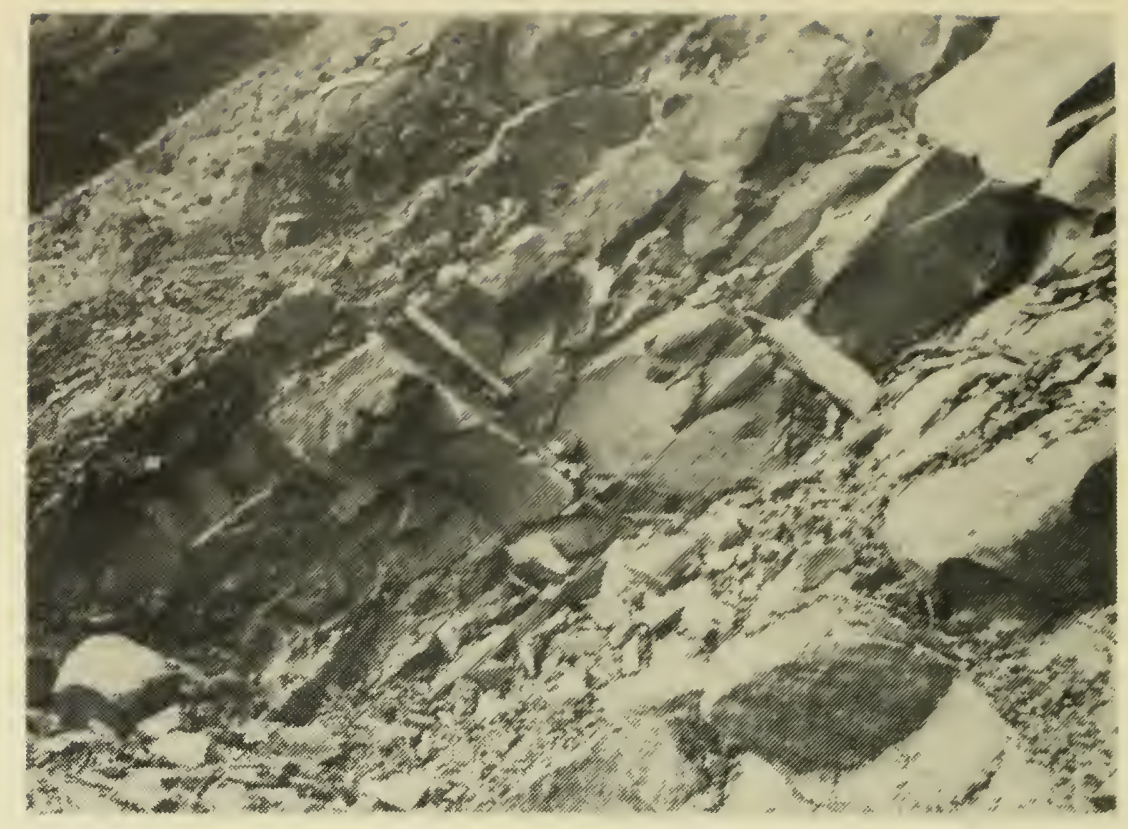

Fig. 3. Detail of the strata in the fossil quarry.

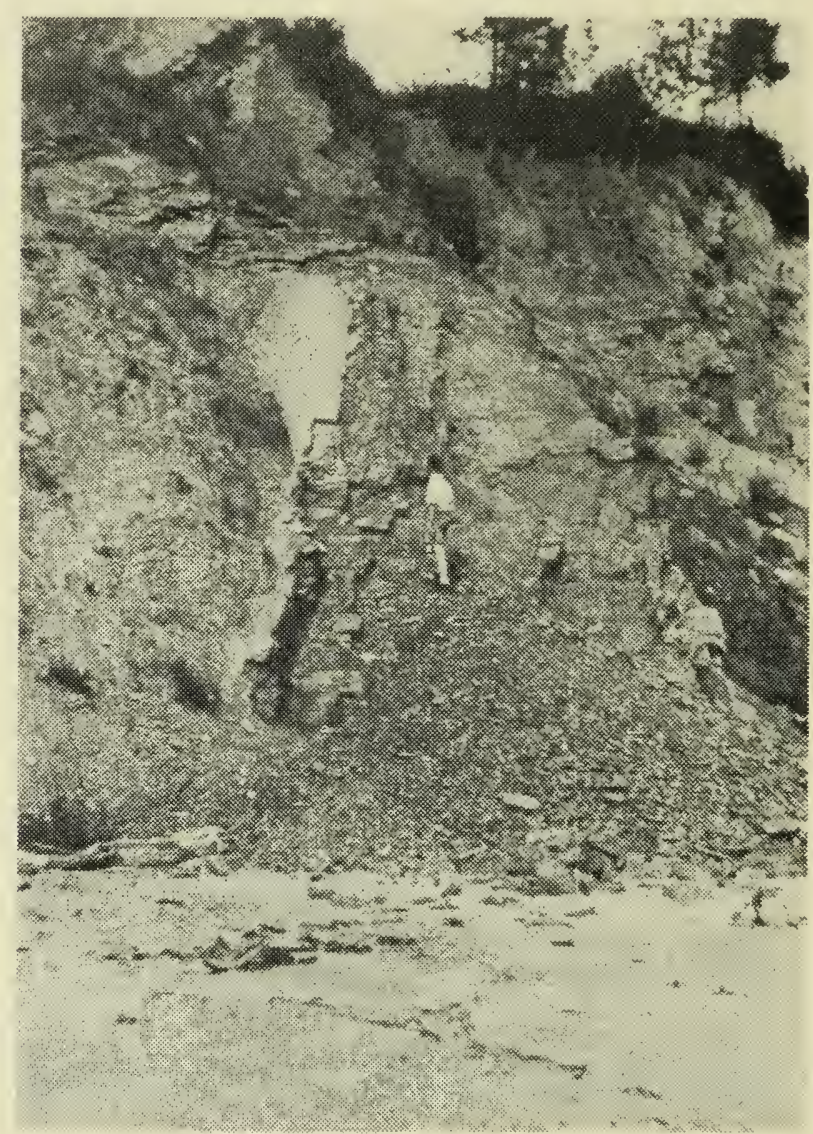

Fig. 2. View of D'Aiguillon fossil fish locality from the beach. 
Published by authority of the Board of Trustees

Royal Ontario Museum

Toronto, Canada 






\section{Don is sy}

WHAL OF 
